\title{
KONSELING GIZI, KUALITAS DIIT BERBASIS PANGAN LOKAL DENGAN KADAR GLUKOSA DARAH PENDERITA DIABETES MELLITUS TIPE II DI WILAYAH KERJA PUSKESMAS BAHU
}

\author{
Rivolta G.M.Walalangi ${ }^{1}$, Muksin Pasambuna ${ }^{2}$, Rudolf B. Purba ${ }^{3}$, Dan \\ Agung Suryohadi ${ }^{3}$ \\ Jurusan Gizi Poltekkes Kemenkes Manado \\ Alamat Korespondensi: aca308@gmail.com
}

\begin{abstract}
Diabetes Mellitus is a group of chronic disease which is characterized by increased levels of glucose in the blood due to disorders of the body's metabolism system, in which the pancreas organ incapable of producing the hormone insulin according to needs of the body. Nutritional counselling with quality local food based diit can help control blood glucose levels. This research aims to identify the difference in blood glucose levels and the value of quality diit type II diabetes mellitus patients before and after given nutritional counseling with quality local food based diit. This type of research is Pre Experimental research using one group pretestposttest design. The number of samples is determined by purposive sampling counted 31 people. Data analysis using Wilcoxon and T-test analysis. The Wilcoxon analysis with significance level of $95 \%$ can be seen to produce significant difference in pre-post glycemic index component with $p=0,000(p<0,05)$ and diversity of prepost food with $p=0,002(p<0,05)$. In the result of $T$-test for pre-post blood glucose variable, there was no significant difference $p=0,105(p>0,05)$. However, there was a range of decreased glucose levels before and after in 22 respondents with an average decrease of $11.42 \mathrm{mg} / \mathrm{dL}$. Conclusion there was no difference of blood glucose level before and after nutrition counseling with quality of diet based on local food.
\end{abstract}

\section{Keywords: Nutrition Counseling, Quality Diit Based Local Food, Blood Glucose Level}

\section{PENDAHULUAN}

Prevalensi Diabetes Mellitus di dunia adalah 1,9\% dan telah menjadikan DM sebagai penyebab kematian urutan ke tujuh di dunia sedangkan tahun 2012 angka kejadian Diabetes Mellitus didunia adalah sebanyak 371 juta jiwa dimana proporsi kejadian Diabetes Mellitus tipe 2 adalah 95\% dari populasi dunia yang menderita Diabetes Mellitus. Estimasi terakhir IDF, terdapat 382 juta orang yang hidup dengan diabetes di dunia pada tahun 2013. Pada tahun 2035 jumlah tersebut diperkirakan akan meningkat menjadi 592 juta orang. Diperkirakan dari 382 juta orang tersebut, 175 juta di antaranya belum terdiagnosis, sehingga terancam berkembang progresif menjadi komplikasi tanpa disadari dan tanpa pencegahan. ${ }^{1)}$ 
Profil Kesehatan Provinsi Sulawesi Utara menunjukkan penyakit Diabetes Mellitus termasuk dalam sepuluh penyakit menular menonjol dan berada pada urutan kelima setelah TBC Paru. Jumlah kasus Diabetes Mellitus di Sulawesi Utara sebanyak 3652 kasus pada tahun $2016^{2)}$. Puskesmas Bahu merupakan salah satu puskesmas yang berada di Kota Manado dengan rata-rata jumlah penderita diabetes mellitus 52 orang.

Kualitas diet yang baik direfleksikan sebagai pola diet yang ditandai dengan tingginya asupan sayuran, buah-buahan, biji-bijian utuh, asupan alkohol sedang, rendahnya asupan daging merah serta produk olahan daging, garam, minuman manis, dan lemak trans. Tingginya kualitas diet pada pada laki-laki diabetes dan prediabetes dikaitkan dengan penurunan tekanan darah sistolik dan diastolik, total kolestrol, dan gula darah puasa, sedangkan pada wanita, terdapat penurunan kolestrol total, gula darah puasa, kadar insulin plasma puasa, gula darah 2 jam postprandial, dan peningkatan sensitivitas insulin pada individu dengan kualitas diet yang tinggi ${ }^{3)}$.

Pangan Lokal adalah makanan yang dikonsumsi oleh masyarakat setempat sesuai dengan potensi dan kearifan lokal. (UUD RI No.18, 2012). Lebih Dari 90 persen masalah kesehatan terkait dengan makanan. Faktor penentu mutu makanan adalah keanekaragaman jenis pangan, keseimbangan gizi dan keamanan pangan. Ketidakseimbangan gizi akibat konsumsi pangan yang tidak beraneka telah membawa dampak pada munculnya masalah gizi ganda di Indonesia, yaitu gizi kurang maupun gizi lebih ${ }^{4)}$.

Berdasarkan data di atas, maka peneliti tertarik untuk melakukan penelitian tentang Bagaimana pengaruh konseling gizi dengan kualitas diit berbasis pangan lokal terhadap pengendalian kadar glukosa darah pada penderita Diabetes Mellitus tipe II rawat jalan di Puskesmas Bahu.

\section{METODE}

Jenis penelitian ini adalah penelitian Pre Eksperimental dengan menggunakan rancangan one group pretest-posttest. Penelitian dilaksanakan selama 2 minggu yaitu yaitu tanggal 30 April - 14 Mei 2018 di wilayah kerja Puskesmas Bahu. Populasi dalam penelitian ini adalah semua penderita Diabetes Mellitus tipe II rawat jalan di Puskesmas Bahu. Sampel dalam penelitian ini berjumlah 31 responden.

Data yang dikumpulkan dalam penelitian ini yaitu : Data identitas diri, Data hasil pemeriksaan glukosa darah puasa, dan data skor kualitas diit dengan menggunanakan formulir recall 24 jam. Selanjutnya sebagai perlakuain responden diberikan konseling gizi yang berbasis pangan lokal Analisis data diawali dengan analisis univariat pada karakteristik responden kemudian uji normalitas dilanjutkan dengan analisis bivariat T-test yang dilanjutkan dengan uji analis Poshock ( Wilcoxon-test)

\section{HASIL}

Karakteristik subjek dalam penelitian ini terdiri dari perempuan 17 responden $(54,8 \%)$ dan laki-laki 14 responden $(45,2 \%)$ paling banyak pada kelompok umur 48 - 
54 tahun yaitu 22 orang (70.96\%) dengan tingkat pendidikan responden terbanyak adalah SMA/SLTA dan pada umumnya bekerja sebagai wiraswasta

Status gizi responden berdasarkan Indeks masa Tubuh menunjukkan terbanyak responden dengan berat badan lebih 16 orang $(61,3 \%)$ dan sisanya mempunyai status gizi normal. Hasil analisis paired sample $t$ test menunjukkan terdapat perbedaan kualitas diet sebelum dan sesudah pemberian konseling $(p<0.05)$. Hasil penelitian ini menunjukkan terdapat perbedaan kadar glukosa darah sebelum dan sesudah pemberian konseling tentang kualitas diet DM dengan memperhitungkan indeks glikemik bahan makanan $(p<0.05)$

\section{PEMBAHASAN}

Sebagian besar responden dalam penelitian ini berjenis kelamin perempuan. Perempuan lebih berisiko terkena DM tipe-2 dibandingkan laki-laki ${ }^{5}$. ' Berdasarkan usia, sebagian besar responden berusia 48 tahun keatas berjumlah 12 responden $(38,7 \%)$. Hasil penelitian ini didukung oleh hasil penelitian dari Fatimah (2015) yang menyatakan bahwa usia yang terbanyak terkena Diabetes Mellitus adalah $>45$ tahun.

Sebagian besar pendidikan responden adalah SMA/SLTA sebanyak 11 responden dengan prevalensi $35,5 \%$. Hal ini sejalan dengan penelitian yang dilakukan Pasaribu (2014). Berdasarkan jenis pekerjaan, sebagian besar responden bekerja sebagai wiraswasta sebanyak 11 responden dengan prevalensi 35,5\%. Hal ini sejalan dengan penelitian yang dilakukan Triana dkk (2015). Berdasarkan status gizi, sebagian besar responden memiliki status gizi berat badan lebih sebanyak 19 responden dengan prevalensi $61,3 \%$. Hal ini sejalan dengan penelitian yang dilakukan Prasetyani dan Sodikin (2017) dalam penelitiannya menyimpulkan bahwa seseorang yang mengalami kelebihan berat badan beresiko 5,45 kali lebih tinggi mengalami DM tipe 2 dibandingkan yang tidak mengalami kelebihan berat badan.

\section{Konseling Gizi dan Kualitas Diit Berbasis Pangan Lokal}

Hasil analisis menunjukkan perbedaan yang bermakna pada komponen indeks glikemik pre-post test dengan keberagaman jenis bahan makanan preposttest $(p<0,05)$. Asupan indeks glikemik mengalami penurunan yang awalnya indeks glikemik tinggi menjadi indeks glikemik rendah pada 22 responden. Untuk komponen keberagaman bahan makanan mengalami peningkatan yang awalnya didominasi dengan keberagaman bahan makanan dengan kategori sedang dan buruk setelah diberikan konseling responden mengalami peningkatan menjadi kategori sedang dan baik pada 11 responden.

Hal ini sejalan dengan penelitian yang dilakukan sebelumnya oleh Rowa dkk (2014) menyimpulkan peran indeks glikemik dalam penatalaksanaan makanan pada penderita diabetes adalah memberikan cara mudah untuk memilih makanan yang tidak menaikkan kadar glukosa darah secara drastis. Dengan diketahuinya indeks glikemik pangan, maka penderita diabetes dengan mudah memilih makanan yang tidak cepat menaikkan kadar gula darah.

Menurut penelitian yang dilakukan Widya dkk (2015), perubahan kualitas diet kelompok kontrol berbeda signifikan dengan perubahan kualitas diet pada kelompok 
perlakuan. Konseling gizi individu dan kelompok terbukti memperbaiki kualitas diet pada penderita diabetes mellitus. Konsumsi sayur, buah, susu, daging, dan kacangkacangan mengalami peningkatan yang signifikan pada kelompok perlakuan hal ini disebabkan adanya pemberian edukasi diet seimbang diabetes mellitus pada sesi konseling yang dijalani oleh subjek.

\section{Konseling Gizi dengan Kadar Glukosa Darah Puasa}

Dalam penelitian ini hasil analisis diperoleh tidak ada pengaruh yang bermakna pada glukosa darah sebelum dan sesudah penelitian $p=0,105(p>0,05)$. Akan tetapi, dapat dilihat terjadi range penurunan pada kadar glukosa darah sebelum dan sesudah dilakukan konseling gizi pada 22 responden dengan rata-rata penerunan $11,42 \mathrm{mg} / \mathrm{dl}$.

Hal ini sejalan dengan penelitian yang dilakukan oleh Nunung (2015) yang menyimpulkan bahwa ada hubungan yang bermakna antara konsultasi gizi terhadap kadar gula darah pada pasien Diabetes Mellitus Tipe II, dimana diperoleh nilai $\mathrm{P}<$ 0,05. Menurut Domili dkk (2017) dalam penelitiannya menyimpulkan bahwa kadar glukosa darah puasa sesudah penelitian pada kelompok yang di beri konsultasi gizi penurunanya lebih besar daripada kelompok yang diberi konseling gizi.

\section{KESIMPULAN}

Terdapat perbedaan rata-rata kadar glukosa darah sebelum dan sesudah konseling gizi. Kualitas diit berbasis pangan lokal dapat mengendalikan kadar glukosa darah penderita Diabetes Mellitus tipe II dengan memperhitungkan keberagaman jenis bahan makanan dengan indeks glisemik rendah.Saran untuk Ahli Gizi atau pelaksanan gizi di Puskesmas Bahu dapat menggiatkan konseling gizi berbasis pangan lokal baik untuk meningkatkan kualitas diit penderita diabetes melitus.

\section{DAFTAR PUSTAKA}

Dinkes Sulut, (2016). Profil Kesehatan Provinsi Sulawesi Utara 2015, UPTD BALAI DATA SURVEILANS DAN SIK, Dinas Kesehatan Provinsi Sulawesi Utara.

Domili, I. Ruhamayanti, N. A. Dan Saputra, A. (2017). Gambaran Kadar Glukosa Darah Puasa Sebelum Dan Sesudah Diberi Konseling Gizi Konsultasi Gizi Pasien Diabetes Mellitus Tipe 2 Di RSUD dr. M. M. Dunda Limboto. Jurusan Gizi, Politeknik Kesehatan Gorontalo. Journal Health And Nutrition Vol III. No. I 2017.

Fatimah, R. N. (2015). Diabetes Melitus Tipe 2. Artikel Review. Fakultas Medis, Universitas Lampung. Lampung.

International Diabetes Federation (IDF). (2014). GLOBAL DIABETES SCORERECARD TRACKING PROGRESS FOR ACTION. Brussels, Belgium.

Muslihah, N., Winarsih, S., Soemardini, Zakaria, AS, Zainudiin. (2013). Kualitas diet dan hubungannya dengan pengetahuan gizi, status sosial ekonomi, dan status gizi. Jurusan IImu Gizi, Fakultas Kedokteran, Universitas Brawijaya, Malang. Jurusan Pendidikan Kedokteran, Fakultas Kedokteran, Universitas Brawijaya, Malang. Jurnal Gizi pangan Vol. 8, No. 1, Maret 2013.

Nunung, S. M. (2015). Pengaruh Konsultasi Gizi Terhadap Asupan Karbohidrat dan Kadar Gula Darah Pasien Diabetes Mellitus Tipe II di Poliklinik Endokrin 
Rumah Sakit Umum Daerah dr. Zainoel Abidin Banda Aceh. Jurnal Kesehatan IImiah Nasuwakes Vol. 8 No. 2.

Pasaribu, S., (2014). Distribusi Umur, Jenis Kelamin, Tingkat Pendidikan, Pekerjaan dan Jenis Komplikasi Pada Penderita DM Tipe II Dengan Komplikasi yang Dirawat Inap Di RSUD DR. Pirngadi Medan Tahun 2012. Fakultas Kedokteran. Universitas HKBP Nommensen. Medan. Sumatera Utara. Skripsi dipublikasikan.

Prasetyani, D. dan Sodikin. (2017). Analisis Faktor Yang Mempengaruhi Kejadian Diabetes Mellitus (DM) Tipe 2. Vol.X. No.2, September 2017.

Presiden RI. (2012). Undang-Undang Dasar Republik Indonesia Nomor 18 Tahun 2012 Tentang Pangan. Dewan Perwakilan Rakyat RI dan Presiden RI.

Rowa, S. S., Fanny, L., Chaerunnimah. (2014) Identifikasi Penggunaan Bahan Makanan Indeks Glikemik Rendah dan Kadar Gula Darah Pasien Diabetes Mellitus Tipe 2 di RSUD Salewangang Maros. Media Gizi Pangan. Vol. XVII, Edisi 1, 2014.

Triana, R., Karim, D., Jumaini, (2015). Hubungan Tingkat Pengetahuan Pasien Diabetes Mellitus Tentang Penyakit dan Diet Dengan Kepatuhan Dalam Menjalankan Diet Diabetes Mellitus. RSUD Arifin Ahmad Pekanbaru. Program Studi Ilmu Keperawatan. Universitas Riau.

Wicaksono, R. P. (2011). Faktor-faktor Yang Berhubungan dengan Kejadian Diabetes Mellitus Tipe 2 (Studi Kasus di Poliklinik Penyakit Dalam Rumah Sakit Dr. Kariadi). Skripsi dipublikasikan.

Widya, S. S., Budi P. L., Purba, M. Br. (2015). Konseling gizi mempengaruhi kualitas diet pasien diabetes mellitus tipe 2 di RSUP Dr.Sardjito Yogyakarta. Indonesia Journal Nutrition Dietisien. Vol. 3, No. 1, Januari 2016 